\title{
PENGARUH KONSENTRASI ETANOL TERHADAP AKTIVITAS ANTIOKSIDAN EKSTRAK RIMPANG ILALANG (Imperata cylindrica (L) Beauv.) PADA EKSTRAKSI MENGGUNAKAN GELOMBANG ULTRASONIK
}

\author{
The Effect of Ethanol Concentration on Antioxidant Activity of Cogon grass Rhizome \\ (Imperata cylindrica (Linn.) Beuv.) Extract Using Ultrasonic Wave
}

\author{
Corry Permatasari Suhendra ${ }^{1)}$, I Wayan Rai Widarta ${ }^{2)}$, Anak Agung Istri Sri Wiadnyani ${ }^{2)}$ \\ ${ }^{1)}$ Mahasiswa Program Studi Imu dan Teknologi Pangan, Fakultas Teknologi Pertanian, Unud \\ ${ }^{2}$ Dosen Program Studi Imu dan Teknologi Pangan, Fakultas Teknologi Pertanian, Unud \\ Kampus Bukit Jimbaran, Badung-Bali
}

\begin{abstract}
This research porpose to determine the appropiate concentration of ethanol to obtain the highest antioxidant activity of cogon grass rhizome (Imperata cylindrica (Linn.) Beuv.) extract using ultrasonic wave. This research used a completely randomized design method with the treatment of concentration ethanol which consisted of six levels : 40, 50, 60,70, 80 and 90\%. The whole treatment was repeated three times to obtain 18 units of the experiment. The data were analyzed by ANOVA, if the treatment showed the influenced then it continued by Duncan test. The result showed that the best treatment is using ethanol $70 \%$ with characteristic extract : yield was $14.13 \%$, total phenolic was $129.57 \mathrm{mgGAE}$ (Gallic Acid Equivalent)/g extract, total flavonoid was $90.91 \mathrm{mgQE}$ (Quercetin Equivalent) $/ \mathrm{g}$ extract and antioxidant activity was $56.03 \%$ with the IC50 value $0.098 \mathrm{mg} / \mathrm{ml}$
\end{abstract}

Keywords : cogon grass rhizome, concentration ethanol, antioxidant activity, ultrasonic wave

\section{PENDAHULUAN}

Ilalang (Imperata cylindrica (L) Beauv.) merupakan tumbuhan yang dikenal sebagai gulma (Kinho et al., 2011). Menurut Kusuma dan Zaky (2005) gulma didefinisikan secara sederhana sebagai tumbuhan yang tidak dikehendaki dan merugikan. Tumbuhan ini merugikan karena dapat bersaing dalam memperebutkan ruang tumbuh, unsur hara dan udara dengan tanaman budidaya lain. Namun, gulma juga memiliki sisi positif karena dapat digunakan sebagai salah satu pangan fungsional, contohnya ialah ilalang. Rimpang pada ilalang sering digunakan sebagai sumber pangan fungsional karena mengandung antioksidan alami. Salah satu produk pangan fungsional berbasis rimpang ilalang ialah dalam bentuk teh herbal (Ekaputra, 2013).

Rimpang ilalang memiliki banyak kandungan kimia, salah satunya adalah senyawa fenolik. Senyawa fenolik dan flavonoid pada rimpang ilalang dapat dimanfaatkan sebagai sumber antioksidan (Dhianawanty dan Ruslin, 2015 ; Sari, 2014). Flavonoid dapat berperan sebagai antioksidan karena mengandung gugus hidroksil yang terikat pada karbon cincin aromatik sehingga dapat menangkap radikal bebas dengan cara mendonorkan elektron (reduktor) sehingga menghasilkan produk yang lebih stabil serta menghambat reaksi berantai radikal bebas (Saxena et al., 2013; Plaza et al., 2014).

*Korespondensi Penulis:

Email: corrypermata@gmail.com ${ }^{1}$ 
Ekstraksi pada rimpang ilalang telah dilakukan oleh Wong et al., (2012) yang menggunakan metode remaserasi selama $2 \mathrm{x}$ 24 jam dengan pelarut etanol $90 \%$ mengandung total fenol 3,05 $\mathrm{mg} \mathrm{GAE} / \mathrm{g}$ dan total flavonoid sebesar $1,02 \mathrm{mg} \quad \mathrm{QE} / \mathrm{g}$. Penelitian lain yang dilakukan oleh Dhianawanty dan Ruslin (2015) melaporkan bahwa ektraksi rimpang ilalang menggunakan metode maserasi dengan pelarut metanol memiliki aktivitas antioksidan dengan nilai IC50 sebesar $0,32 \mathrm{mg} / \mathrm{mL}$ dan total polifenol sebesar 1,53\% EAG (Ekivalen Asam Galat).

Senyawa fenolik dan flavonoid pada rimpag ilalang dapat diperoleh dengan cara ekstraksi. Metode ekstraksi dapat dilakukan dengan berbagai cara diantaranya ialah : maserasi, perkolasi dan sokletasi. Proes ekstraksi rimpang ilalang pada penelitian ini menggunakan bantuan gelombang ultrasonik. Metode ini merupakan metode maserasi yang dimodifikasi dengan menggunakan bantuan gelombang ultrasonik yaitu gelombang akuistik dengan frekuensi lebih dari $16 \mathrm{kHz}$. Keuntungan metode ekstraksi maserasi dengan bantuan gelombang ultrasonik adalah dapat mempercepat proses ekstraksi. Hal itu dikarenakan pengunaan gelombang ultrasonik dapat menimbulkan efek kavitasi yang dapat memecah dinding sel bahan sehingga komponen bioaktif keluar dengan mudah dan didapatkan hasil ekstrak yang maksimal dengan proses yang lebih singkat. Keuntungan lain dari ekstraksi maserasi menggunakan bantuan gelombang ultrasonik ialah meningkatkan rendemen ekstrak dibandingkan dengan metode ekstraksi konvensional seperti maserasi (Kuldiloke, 2002).

Faktor yang mempengaruhi laju ekstraksi adalah tipe ekstraksi, persiapan sampel, waktu ekstraksi, jumlah sampel, suhu, dan jenis pelarut (Utami, 2009). Umumnya flavonoid ditemukan berikatan dengan gula membentuk glikosida yang menyebabkan senyawa ini mudah larut dalam pelarut polar (Hanani, 2016). Dengan demikian, selama proses ekstraksi flavonoid akan terlarut dalam larutan penyari yang sesuai dengan kepolarannya. Kelarutan suatu zat ke dalam suatu pelarut sangat ditentukan oleh kecocokan sifat atau struktur kimia antara zat terlarut dengan pelarut, yaitu like disolves like (Hismath et al., (2011) dalam Widarta dan Arnata, 2017). Pelarut etanol adalah pelarut polar sehingga pelarut ini sering digunakan untuk mengindentifikasi senyawa flavonoid (Arifin et al., 2006).

Selain jenis pelarut perbedaan konsentrasi juga mempengaruhi hasil ekstraksi. Perbedaan konsentrasi etanol dapat mengakibatkan perubahan polaritas pelarut sehingga mempengaruhi kelarutan senyawa bioaktif salah satunya ialah flavonoid (Zhang et al., 2009). Berikut beberapa hasil penelitian menggunakan metode ekstraksi maserasi berbantu gelombang ultrasonik dengan menghasilkan konsentrasi pelarut terbaik terhadap parameter uji dari masing-masing ekstrak: Penelitian yang dilakukan Huang et al., (2009) melaporkan bahwa ekstraksi Folium eucommiae terbaik menggunakan pelarut etanol $40 \%$ menghasilkan total flavonoid tertinggi sebesar 17,2\%. Wang et al., (2012) melaporkan bahwa ekstraksi rimpang Sparganii selama 29,4 menit dengan pelarut etanol 53,62\% menghasilkan total flavonoid tertinggi sebesar 94,62\%. Sementara itu, Sungthong et al., (2014) melaporkan bahwa ekstraksi daun murbey menggunakan pelarut etanol 60\% menghasilkan aktivitas antioksidan tertinggi yaitu sebesar 89,88\%. Yuswi (2017) melaporkan bahwa ekstraksi bawang dayak dengan etanol $96 \%$ selama 30 menit menghasilkan total flavonoid dan total fenolik tertinggi masing-masing 106,03 $\mathrm{mg} \mathrm{QE} / \mathrm{g}$, 240,62 mg GAE/g serta nilai IC50 sebesar $52,38 \mathrm{ppm}$. Belum ditemukan data tentang konsentrasi pelarut etanol yang tepat untuk 
ekstraksi pada rimpang ilalang dengan maserasi menggunakan gelombang ultrasonik. Oleh karena itu, perlu dilakukan penelitian terkait pengaruh konsentrasi pelarut etanol aktivitas antioksidan ekstrak rimpang ilalang menggunakan gelombang ultrasonik.

\section{METODE PENELITIAN}

\section{Tempat dan Waktu Penelitian}

Penelitian ini dilaksanakan di Laboratorium Biokimia dan Nutrisi, Analisis Pangan Program Studi Ilmu dan Teknologi Pangan, Fakultas Teknologi Pertanian, UPT. Biosains dan Bioteknologi dan UPT. Kimia Analitik Universitas Udayana. Penelitian ini dilakukan pada bulan April 2018 sampai dengan bulan Juli 2018.

\section{Bahan dan Alat}

Bahan yang digunakan dalam penelitian kali ini ialah : rimpang ilalang yang diperoleh dari daerah Jimbaran, Bali, aquadest, pelarut etanol p.a (Merck), standar kuersetin (Sigma), reagen Folin-Ciocalteu (Merck), sodium karbonat $\left(\mathrm{Na}_{2} \mathrm{CO}_{3}\right)$ (Merck), $\mathrm{NaNO}_{2}$ (Merck), $\mathrm{AlCl}_{3}$ (Merck), NaOH (Merck), 1,1-diphenyl2-picryldrazil (DPPH) (SigmaAldrich) dan standar asam galat (Sigma).

Alat yang digunakan dalam penelitian kali ini ialah : oven (Labo DO 225), spektrofotometer UV-Vis (Biocheme SN 133467), ultrasonic bath (Branson 2200), rotary vacuum evaporator (Buchi), water bath (Memmert), timbangan analitik (Sartorius), alumunium foil, vortex, kertas Whatman No.1, blender (Miyako BL-101 PL), ayakan 60 mesh, rak tabung, pipet ukur $1 \mathrm{ml}$ (Iwaki), pipet ukur $2 \mathrm{ml}$ (Pyrex), pipet ukur $10 \mathrm{ml}$ (Pyrex), corong, pinset, desikator, stopwatch dan alatalat gelas.

\section{Rancangan Percobaan}

Penelitian ini menggunakan Rancangan Acak Lengkap (RAL) dengan perlakuan konsentrasi pelarut etanol terdiri dari 6 taraf yaitu : 40\%, 50\%, 60\%, 70\%, 80\%, dan 90\%. Perlakuan ini diulang sebanyak tiga kali sehingga diperoleh 18 unit percobaan. Data yang diperoleh dianalisis menggunakan sidik ragam dan apabila terdapat pengaruh perlakuan terhadap variabel yang diamati dilanjutkan dengan uji Duncan (Steel and Torrie, 1993).

\section{Pelaksanaan Penelitian}

1. Persiapan Sampel

Rimpang ilalang yang digunakan ialah rimpang ilalang berwarna putih. Rimpang kemudian dicuci, lalu dikeringkan menggunakan oven pada suhu $50^{\circ} \mathrm{C}$ selama 24 jam (kadar air $\leq 10 \%$ dengan kriteria penampakan rimpang mengkerut dan mudah dipatahkan). Proses pembuatan bubuk dilakukan dengan menggunakan blender dan diayak dengan ayakan ukuran 60 mesh (Widarta dan Arnata (2017), yang telah dimodifikasi). Bubuk yang telah diayak tersebut kemudian ditimbang.

\section{Proses Pembuatan Ekstrak Rimpang Ilalang}

Sebanyak $10 \mathrm{~g}$ bubuk rimpang ilalang ditambahkan pelarut etanol dengan konsentrasi sesuai perlakuan $(40 \%, 50 \%, 60 \% 70 \%, 80 \%$, dan 90\%). Perbandingan bahan dengan pelarut adalah 1:10 (b/v) kemudian ditempatkan dalam ultrasonic bath selama 30 menit pada suhu kamar dengan frekuensi $47 \mathrm{kHz}$. Selanjutnya disaring dengan kertas saring whatman no 1. Filtrat yang diperoleh dipekatkan dalam rotari evaporator vakum pada suhu $30^{\circ} \mathrm{C}$ sehingga diperoleh ekstrak kasar (Widarta dan Arnata (2017), yang telah dimodifikasi).

\section{Parameter yang Diamati}

Parameter yang diamati pada penelitian ini meliputi rendemen ekstrak (Handayani et al., 2016), total fenol menggunakan metode FolinCiocalteau (Garcia et al., 2007), total flavonoid dengan spektofotometer menggunakan reagen $\mathrm{AlCl} 3$ (Josipovic et al, 
2016), aktivitas penghabatan radikal DPPH dan IC50 (Shah dan Modi, 2015).

\section{HASIL DAN PEMBAHASAN}

Nilai rata-rata rendemen, total fenol, total flavonoid dan aktivitas penghambat radikal DPPH ekstrak rimpang ilalang pada perlakuan konsentrasi pelarut etanol dapat dilihat pada Tabel 1.

Tabel 1. Nilai rata- rata rendemen, total fenol, total flavonoid dan aktivitas aktivitas penghambat radikal DPPH ekstrak rimpang ilalang pada perlakuan konsentrasi pelarut etanol.

\begin{tabular}{ccccc}
\hline $\begin{array}{c}\text { Konsentras } \\
\text { i Etanol } \\
\mathbf{( \% )}\end{array}$ & $\begin{array}{c}\text { Rendemen } \\
\text { Ekstrak (\%) }\end{array}$ & $\begin{array}{c}\text { Total Fenolik (mg } \\
\text { GAE/g ekstrak) }\end{array}$ & $\begin{array}{c}\text { Total Flavonoid } \\
\text { (mg QE/g ekstrak) }\end{array}$ & $\begin{array}{c}\text { Aktivitas Pengahambatan } \\
\text { Radikal DPPH (\%) }\end{array}$ \\
\hline $\mathbf{4 0}$ & $10,17 \pm 0,37 \mathrm{~d}$ & $50,41 \pm 0,74 \mathrm{f}$ & $41,74 \pm 0,68 \mathrm{f}$ & $19,09 \pm 0,69 \mathrm{f}$ \\
$\mathbf{5 0}$ & $11,46 \pm 0,72 \mathrm{c}$ & $56,58 \pm 0,69 \mathrm{~d}$ & $47,62 \pm 0,38 \mathrm{e}$ & $24,69 \pm 0,41 \mathrm{e}$ \\
$\mathbf{6 0}$ & $11,74 \pm 0,79 \mathrm{bc}$ & $98,28 \pm 0,70 \mathrm{~b}$ & $62,55 \pm 0,50 \mathrm{c}$ & $30,71 \pm 0,43 \mathrm{c}$ \\
$\mathbf{7 0}$ & $14,13 \pm 0,68 \mathrm{a}$ & $129,57 \pm 1,58 \mathrm{a}$ & $90,91 \pm 0,78 \mathrm{a}$ & $56,03 \pm 0,90 \mathrm{a}$ \\
$\mathbf{8 0}$ & $12,85 \pm 0,47 \mathrm{~b}$ & $75,80 \pm 0,75 \mathrm{c}$ & $71,15 \pm 0,67 \mathrm{~b}$ & $39,51 \pm 0,76 \mathrm{~b}$ \\
$\mathbf{9 0}$ & $11,09 \pm 0,73 \mathrm{~cd}$ & $54,41 \pm 0,22 \mathrm{e}$ & $49,59 \pm 0,41 \mathrm{~d}$ & $28,09 \pm 0,49 \mathrm{~d}$ \\
\hline
\end{tabular}

Keterangan : Notasi yang sama pada kolom yang sama menunjukan perlakuan berbeda tidak nyata $(\mathrm{P}>0,05)$

\section{Rendemen Ekstrak}

Hasil analisis sidik ragam menunjukkan bahwa perlakuan konsentrasi pelarut etanol berpengaruh sangat nyata $(\mathrm{P}<0,01)$ terhadap rendemen ekstrak rimpang ilalang. Tabel 1. menunjukkan bahwa rendemen ekstrak semakin meningkat sampai konsentrasi etanol $70 \%$ yaitu sebesar $14,13 \%$ dan rendemen ekstrak yang diperoleh menurun pada konsentrasi etanol $80 \%$ dan 90\%. Hal ini disebabkan oleh senyawa kimia yang terdapat pada rimpang ilalang semakin meningkat kelarutannya hingga konsentrasi etanol $70 \%$ dan mengalami penurunan setelah konsentrasi etanol $70 \%$. Perbedaan konsentrasi pelarut etanol berpengaruh terhadap tingkat polaritas suatu pelarut. Polaritas etanol akan semakin meningkat seiring dengan penurunan konsentrasinya dalam air (Kumoro et al., (2009) dalam Widarta dan Arnata, 2017).

Peningkatan nilai rendemen pada ekstrak rimpang ilalang dipengaruhi oleh senyawa kimia diantaranya ialah senyawa fenolik dan flavonoid. Dimana, rendemen ekstrak akan meningkat seiring dengan peningkatan total fenolik dan flavonoid pada ekstrak rimpang ilalang hingga pada konsentrasi etanol 70\%. Harborne (1973) menyatakan bahwa prinsip dasar dari ekstraksi ialah like dissolves like dimana kelarutan suatu senyawa pada pelarut didasari dari kesamaan polaritas antara pelarut dengan senyawa yang diekstrak.

\section{Total Fenolik}

Hasil analisis sidik ragam menunjukkan bahwa perlakuan konsentrasi pelarut etanol berpengaruh sangat nyata $(\mathrm{P}<0,01)$ terhadap total fenolik ekstrak rimpang ilalang. Tabel 1. menunjukkan bahwa kadar total fenolik akan semakin meningkat sampai pada perlakuan menggunakan pelarut etanol dengan konsentrasi $70 \quad \%$ yaitu sebesar 129,57 mgGAE/g ekstrak. Hasil serupa juga dilaporkan oleh Adriana (2017) bahwa etanol $70 \%$ mampu menghasilkan total fenolik tertinggi pada ekstraksi rumput laut Padina minor dan Sargassum polycytum. Demikian pula pada daun alpukat dengan total fenolik tertinggi diperoleh pada konsentrasi etanol 70 $\%$ (Widarta dan Arnata, 2017).

Etanol merupakan pelarut yang dapat melarutkan senyawa dari yang kurang polar hingga polar, salah satu senyawa yang dapat dilarutkan oleh etanol ialah senyawa fenolik. Etanol dapat melarutkan senyawa fenolik karena mampu mendegradasi dinding sel 
sehingga senyawa bioaktif lebih mudah keluar dari sel tanaman. Etanol memiliki gugus hidroksil yang dapat berikatan dengan gugus hidrogen dari gugus hidroksil senyawa fenolik yang menyebabkan peningkatan kelarutan senyawa fenolik dalam etanol. Perbedaan konsetrasi etanol dapat mempengaruhi kelarutan senyawa fenolik didalam pelarut (Prayitno et al., 2016). Semakin tinggi konsentrasi etanol maka semakin rendah tingkat kepolaran pelarutnya (Shadmani, 2004). Suatu zat akan terlarut dan terekstrak dengan baik apabila pelarut yang digunakan memilik tingkat kepolaran yang sama (Sax dan Lewis, (1998) dalam Yuswi, 2017).

\section{Total Flavonoid}

Hasil analisis sidik ragam menunjukkan bahwa perlakuan konsentrasi pelarut etanol berpengaruh sangat nyata $(\mathrm{P}<0,01)$ terhadap total flavonoid ekstrak rimpang ilalang. Tabel 1. menunjukkan bahwa kadar total flavonoid akan semakin meningkat hingga konsentrasi etanol $70 \%$ yaitu sebesar 90,91 $\mathrm{mgQE} / \mathrm{g}$ ekstrak. Penggunaan konsentrasi etanol yang lebih tinggi hingga 90\% mengakibatkan total flavonoid ekstrak yang diperoleh mengalami penurunan. Zhang et al., (2009) menyatakan bahwa pelarut etanol $70 \%$ merupakan pelarut yang cocok untuk melarutkan senyawa flavonoid dari daun lotus karena menghasilkan flavonoid optimum dibandingkan dengan etanol $65 \%$ dan $75 \%$.

Pelarut campuran antara alkohol dan air merupakan pelarut pengekstrak terbaik untuk hampir semua senyawa yang memiliki berat molekul rendah seperti flavonoid (Wijesekera, (1991) dalam Arifianti et al., 2014). Total flavonoid pada rimpang ilalang mengalami peningkatan dari konsentrasi pelarut etanol $40 \%$ hingga konsentrasi etanol $70 \%$. Hal ini dikarenakan, perbedaan konsentrasi etanol dapat mengakibatkan perubahan polaritas pelarut sehingga mempengaruhi kelarutan senyawa bioaktif salah satunya ialah flavonoid (Zhang et al., 2009). Penggunaan pelarut etanol dengan konsentrasi diatas 70\% mengakibatkan penurunan total flavonoid. Pelarut etanol diatas $70 \%$ kurang efektif untuk melarutkan senyawa flavonoid yang memiliki berat molekul rendah. Hal serupa juga dilaporkan pada ekstrak Centella asiatica yang mengalami penurunan total flavonoid dengan perlakuan konsentrasi diatas 70\% (Chew et al., 2011).

\section{Aktivitas Penghambatan Radikal DPPH dan IC50}

Hasil analisis sidik ragam menunjukkan bahwa perlakuan konsentrasi pelarut etanol berpengaruh sangat nyata $(\mathrm{P}<0,01)$ terhadap aktivitas penghambatan radikal DPPH ekstrak rimpang ilalang. Aktivitas penghambatan radikal DPPH menunjukkan aktivitas antioksidan pada ekstrak rimpang ilalang. Tabel 1 menunjukkan bahwa aktivitas antioksidan akan semakin meningkat sampai pada perlakuan menggunakan pelarut etanol dengan konsentrasi $70 \%$ yaitu sebesar $56,03 \%$, namun setelah konsentrasi pelarut etanol $70 \%$ aktivitas antioksidan mengalami penurunan. Nilai aktivitas antioksidan akan meningkat sesuai dengan meningkatnya kandungan total fenolik dan flavonoid yang terdapat dalam ekstrak, namun setelah konsentrasi pelarut optimum aktivitas antioksidan akan berkurang sesuai dengan penurunan total fenolik dan flavonoid yang terdapat pada ekstrak. Total fenolik dan flavonoid ekstrak rimpang ilalang memiliki kolerasi positif dengan aktivitas antioksidan. Senyawa fenol dan flavonoid pada rimpang ilalang dapat dimanfaatkan sebagai sumber antioksidan (Dhianawaty dan Ruslin, 2015; Sari, 2014). Senyawa fenolik termasuk flavonoid dapat berperan sebagai antioksidan karena mengandung gugus hidroksil yang terikat pada karbon cincin aromatik sehingga dapat menangkap radikal bebas (Saxena et al., 2013). Senyawa fenolik dapat bereaksi dengan radikal bebas karena memiliki kemampuan mendonorkan elektron (reduktor) sehingga 
menghasilkan produk yang lebih stabil serta menghambat reaksi berantai radikal bebas (Plaza et al., 2014).

Hasil penelitian menunjukkan bahwa ekstraksi rimpang ilalang menggunakan etanol $70 \%$ memiliki aktivitas antioksidan tertinggi sehingga diuji lanjut untuk menentukan nilai IC50. Hasil pengujian aktivitas antioksidan ekstrak rimpang ilalang dengan pelarut etanol $70 \%$ dalam beberapa konsentrasi dapat dilihat pada Gambar 3.

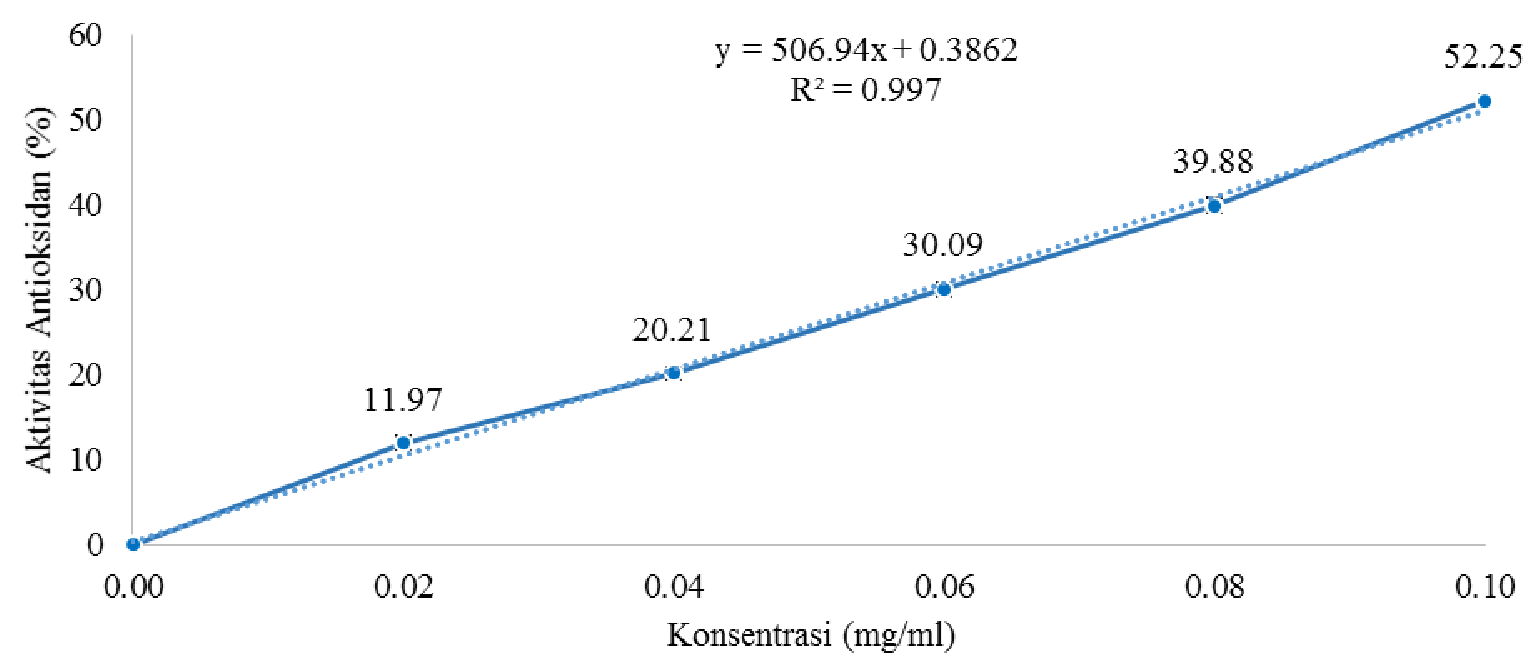

Gambar 3. Grafik hubungan antara aktivitas antioksidan dan konsetrasi ekstrak rimpang ilalang

Gambar 3. menunjukan hubungan antara aktivitas antioksidan (sumbu y) dengan konsentrasi ekstrak (sumbu x) yang diperoleh. Diketahui bahwa semakin tinggi konsentrsi ekstrak maka semakin tinggi juga aktivitas antioksidan. Analisis regresi linier menghasilkan persamaan $\mathrm{y}=506,94 \mathrm{x}+0,3862$ dengan $\mathrm{IC}_{50}$ sebesar $0,098 \mathrm{mg} / \mathrm{ml}$. Jika nilai $\mathrm{IC}_{50}$ semakin kecil maka kemampuan antioksidan semakin besar (Senevirathe et al., 2006).

\section{SIMPULAN DAN SARAN}

\section{Simpulan}

Berdasarkan dari hasil penelitian yang sudah dilakukan, dapat disimpulkan sebagai berikut :

1. Konsentrasi pelarut etanol berpengaruh sangat nyata terhadap rendemen, total fenol, total flavonoid dan aktivitas penghambat radikal DPPH ekstrak rimpang ilalang.
2. Perlakuan pelarut etanol $70 \%$ menghasilkan ekstrak dengan kandungan tertinggi pada parameter uji yaitu : rendemen $14,13 \%$, total fenol $129,57 \mathrm{mg}$ GAE/g ekstrak, total flavonoid $90,91 \mathrm{mg}$ QE/g ekstrak, aktivitas penghambat radikal DPPH 56,03 \% dengan nilai $\mathrm{IC}_{50} 0,098$ $\mathrm{mg} / \mathrm{ml}$.

\section{Saran}

Saran yang dapat penulis berikan yaitu untuk mengekstraksi senyawa bioaktif rimpang ilalang sebaiknya menggunakan etanol dengan konsentrasi $70 \%$ sehingga dapat memperoleh komponen bioaktif dan aktivitas antioksidan dalam rimpang ilalang tertinggi. Selain itu, ekstrak rimpang ilalang dapat dimanfaatkan sebagai bahan dasar suplemen karena mengandung antioksidan. 


\section{DAFTAR PUSTAKA}

Adriana, C.B. 2017. Aktivitas antioksidan dan total fenol Padina minor dan Sargasum polycystum dari perairan kepulauan Seribu. Skripsi S1. Tidak dipublikasikan. Fakultas Perikanan dal Ilmu Kelautan IPB, Bogor.

Arifin, H., N. Anggraini, D. Handayani dan R. Rasyid. 2006. Standarisasi ekstrak etanol daun Eugenia cumini Merr. Jurnal Sains Tek. Farmasi 11(2):88-93.

Arifianti, L., R.C. Oktariana, R.D., I. Kusumawati. 2014. Pengaruh jenis pelarut pengekstraksi terhadap kadar sinensetin dalam ekstrak daun Orthosiphon stamineus Benth. Jurnal Planta Husada 2(1):1-4.

Chew, K.K., M.Z. Khoo, S.Y. Ng, Y.Y. Thoo, W.M.W. Aida dan C.W. Ho. 2011. Effect of ethanol concentration, extraction time and extraction temperature on the recovery of phenolic coumponds and antioxidant capacity of Centella asiatica extract. International Journal of Food Research 18(4):14271435.

Dhianawaty, D. dan Ruslin. 2015. Kandungan total polifenol dan aktivitas antioksidan dari ekstrak metanol akar alang-alang (Imperata cylindrica (L) Beauv.). Jurnal Kedokteran 47(1):60-64.

Ekaputra, F.H. 2013. Uji Aktivitas Antioksidan Sediaan Teh Celup Kombinasi Rimpang Kapulaga (Amomum cardamomum) dan Akar Alang-Alang (Imperata cylindrica) dengan metode peredaman radikal DPPH. Skripsi S1. Tidak dipublikasikan. Fakultas Farmasi UI, Depok.

Garcia, C.A., P. Hevia dan V.C. Gravino. 2007. Correlation of tocopherol, tokotrienol and total polyphenol content in rice bran with different antioxidant capacity assays. Journal of Food Chemistry 102:1228-1232.

Handayani, H., H.S Feronika dan Yunianta. 2016. Ekstraksi antioksidan daun sirsak metode ultrasonic bath (kajian rasio bahan : pelarut dan lama ekstraksi). Jurnal Pangan dan Agroindustri 4(1):262-272.

Harborne, J.B. 1973. Phytochemical Methode. Campman and Hall Ltd, Amerika.

Huang, W., A. Xue, H. Niu, Z. Jia dan J. Wang. 2009. Optimised ultrasonic assited extraction of flavonoid from Follium eucommiae and evaluation of antioxidant activity in multi-test systems in vitro. Journal of Food Chemistry 114:11471154.

Josipovic, A., R. Sudar, A. Sudaric, V. Jurkovic, M.M. Kocar dan A.M. Kulundzic. 2016. Total phenolic and total flavonoid content variability of soybean genotypes in eastern Croatia. Journal Food Science Technology 8(2):60-65.

Kinho, J., D.I.D. Arini., L. Nuraini, Halidah, Y. Kafiar dan M.C.Karundeng. 2011. Tumbuhan Obat Tradisional di Sulawesi Utara Jilid II. Balai Penerbitan Kehutanan Manado, Manado.

Kuldiloke, J. 2002. Effect ultrasound, temperature, and pressure treatment on enzyme activity and quality indicators of fruit and vegetables juices. Desertasi S3. Tidak dipublikasikan. Universitas Berlin, Berlin.

Kusuma, F. R. dan B.M. Zaky. 2005. Tumbuhan Liar Berkhasiat Obat. Agromedia Pustaka, Jakarta. 
Plaza, C.M., L.E Diaz de Torres, R.K. Lucking, M. Vizcaya dan G.E. Medina. 2014. Antioxidant activity, total phenols and flavonoids of lichens from venezuelan andes. Journal of Pharmacy and Pharmacognosy Research 2:138-147.

Prayitno, S.A., J. Kusnadi, E.S. Murtini. 2016. Antioxidant activity of red betel leaves extract (Piper crocatum Ruiz and Pav.) by different concentration of solvents. Journal of Pharmaceutical, Biological and Chemical Science 7(5):1836-1843.

Sari, Y.M. 2014. Efek Rimpang Alang-alang (Imperata cylindrica (L.) P. Beauv) terhadap penurunan tekanan darah. Skripsi S1. Tidak dipublikasikan. Fakultas Kedokteran UKM, Bandung.

Saxena, M., J. Saxena, D. Singh dan A. Gupta. 2013. Phytochemistry of medicinal plants. Journal of Pharmacognosy and Phytochemistry 1(6):168-182.

Senevirathne, M., S. Kim, N. Siriwardhana, J. Ha, K. Lee dan Y. Jeon. 2006. Antioxidant potential of Ecklonia cava on reactive oxygen species scavenging, metal chelating, reducing power and peroxidation inhibiton. Journal of Food Science and Technology International 12:27-38.

Shadmani, A., I. Azhar, F. Mazhar, M.M. Hassan, S.W. Ahmed, I. Ahmad, K. Usmanghani dan S. Shamim. 2004. Kinetic studies on Zingiber offcinale. Journal of Pharmaceutical Sciences 17(1):47-54.

Shah dan Modi.2015. Comparative study of DPPH, ABTS and FRAP assay for determination antioxidant activity. International Journal for Reasearch in Applied Scince and Engineering Technology (IJRATES) 3(4):636-641.
Steel, R.G.D dan J.H. Torrie. 1993. Prinsip dan Prosedur Statistik Suatu Pendekatan Biometric. Penerjemah Bambang Sumantri. PT. Gramedia Pustaka Utama, Jakarta.

Sungthong,B., C. Butimna dan K. Jitsaeng. 2014. Optimized ultrasonic-assted axtraction of antioxidant from murbey (Morus alba L) leaves using multiple linier regression analysis. Journal of Pharmacy and Pharmaceutical Sciences 6 (2):914-917.

Utami. 2009. Potensi daun alpukat (Persea Americana Mill.) sebagai sumber antioksidan alami. Jurnal Teknik Kimia 2(1):56-64.

Wang, X., Q. Wu, Y. Wu, G. Chen, W. Yue dan Q. Liang. 2012. Response optimized ultrasonic- assisted extraction of flavonoid from Sparganii rhizome and evaluation of their in Vitro antioxidant activities. Journal Molecules 17:67696783.

Widarta, I.W.R dan I.W Arnata. 2017. Ekstraksi komponen bioaktif daun alpukat dengan bantuan ultrasonik pada berbagai jenis dan konsentrasi pelarut. Jurnal AGRITECH 37(2):148-157.

Wong, F.C., T.T. Chai dan Y.W. Hoo. 2012. Antioxidant and cytotoxic activities of selected medical herbs used in Malaysia. Journal of Medicine Plants Research 6(16):3169-3175.

Yuswi, N.C.R. 2017. Ekstraksi antioksidan bawang dayak (Eleutherine bawang dayak (Eleutherine palmifolia) dengan metode Ultrasonic bath (kajian jenis pelarut dan lama ekstraksi). Jurnal Pangan dan Agroindustri 5(1):71-79.

Zhang, L., Y. Shan, K. Tang, R. Putheti. 2009. Ultrasound-assited extraction flavonoid 
of lotus (Nelumbo nuficera Gaertn) leaf and evaluation of its anti-fatigue activity. International Journal of Phisical Science 4(8):418-422. 